\title{
VIII. Account of a new operation lately performed with success in France, for restoring sight in certain cases of blindness
}

\section{Demours}

To cite this article: C. Demours (1800) VIII. Account of a new operation lately performed with success in France, for restoring sight in certain cases of blindness, Philosophical Magazine Series 1, 8:30, 148-149, DOI: 10.1080/14786440008562621

To link to this article: http://dx.doi.org/10.1080/14786440008562621

曲 Published online: 18 May 2009.

Submit your article to this journal $[\pi$

Џll Article views: 2

Q View related articles $\longleftarrow$ 


\section{$\left[\begin{array}{lll}148 & \end{array}\right]$}

VIII. Account of a new Operation lately performed with Suecefs in France, for reftoring Sigbt in certain Cafes of Blindnefs. By C. Demours.

DEMOURS, who performed this new and ingenious operation, prefented a memoir on the fubject to the National Inftitute, which was read on the 15 th of June laft. From this memoir the prefent account has been extracted.

The eye is a ball or globe filled with different tranfparent humours, which are contained in feverat membranes. The outermoft of thefe membranes is called the cornea; it is tranfparent, and placed before the iris, which is the coloured part of the eye, and which itfelf forms a fecond membrane; but the latter is not tranfparent, and would prevent the rays of light from penetrating to the hind part of the globe of the eye, were it not pierced with a round hole, called the pupil. A little beyond this hole is the cryftalline humour, forming a kind of lens, through which the rays of light are obliged to pafs; and by means of which they form diftinct images on the retina at the bottom of the eye. The humour containcd in the infide of the globe is called the vitreous humour; it is perfectly tranfparent, as is alfo the aqueous humour, which is placed between the tranfparent cornea and the cryftalline.

C. Sauvages, on whom C. Demours performed the operation which is the fubject of this article, had for feveral years an abfcefs in the cornea, in confequence of which the aqueous humour was entirely wafted, and the tranfparent part of the cornea had become totally white and opake in the right eye, and for about four-fifths in the left eye. This eye is reprefented in the annexed engraving (Plate V. fig. 5). The tranfparent cornea, $\mathrm{C}$, fuffers to be feen towards the upper part but a finall portion of the iris. The white fpot covers entirely the round hole or pupil, which exifs in the centre of the iris, and through which alone the rays of light can pafs.

C. Demours, taking advantage of the tranfparency which ftill exifted towards the upper part of the cornea, made there a fmall aperture, denoted by the letter $\mathrm{A}$; and having introduced 


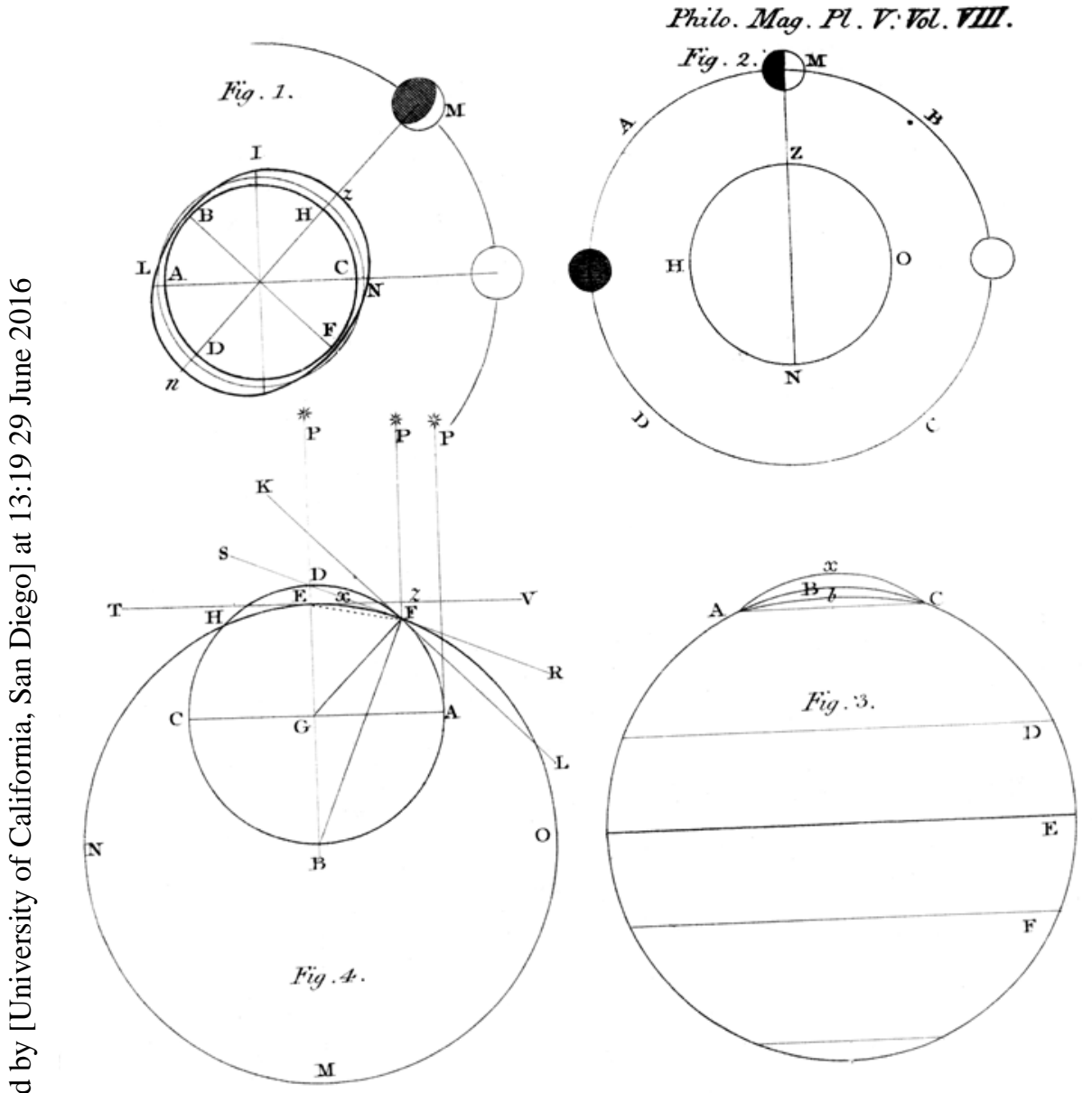


troduced into that aperture a delicate pair of fciftars, made a fmall hole in the iris, of the fize of a feed of forrel, indicated in the engraving by the letter $D$.

Through this hole, made in a non-tranfparent membrane, the rays of light now enter, and form images on the retina at the bottom of the eye. It is, therefore, an artificial pupil which fupplies the place of that covered by the white fpot of the cornea. But as behind this new pupil there is no cryftalline humour to collect the rays with fufficient accuracy on the retina, C. Sauvages is obliged, in order to read, to make ufe of a very convex glafs, fuch as is ufed by perfons who have undergone an operation for the cataract, and who have loft the cryftalline humour. He does not employ the glafs, however, except in cafes which require more diftinct vifron; and he ftill poffeffes the invaluable advantage of feeing well enough to direct his way, and to difcern perfectly every object around him. By means of this ingenious operation, fight in future may be reftored to the greater part of thofe who have loft that faculty by large fpots or white fcars, cafes hitherto confidered as incurable; provided that fome part of the cornea, oppofite to the iris, has remained tranfparent.

IX. On the Cultivation and Ufe of the Syrian Silk-Plant. By J. A. MöLle R, Director of the Weftpbalian Patriotic Society*.

I. Defcription. $\mathrm{THE}$ filk-plant, Afclepias Syriaca LIN known by the old botanifts and our gardeners under the name of Apocynum Syriacum, came originally from Syria and Egypt. It is indigenous alfo in North America, and thrives fo well in Europe, that it would appear that it is fuited for all countries and climates. The root is perennial, and will laft from ten to twenty years. In the month of April it throws out, like afparagus and hops, a great number of thoots, the principal ftem of which rifes to the height of feven or eight feet. This ftem, which is as thick

* From the Tranfactions of the Academy of the Ujiful Sciances at Erfurt. 